\title{
Control of biogenic amines in dry sausages inoculated with dairy-originated bacteriocinogenic Enterococcus faecalis EF-101
}

\author{
Nevijo Zdolec ${ }^{1 *}$, Tanja Bogdanović2 ${ }^{2}$ Valerij Pažin ${ }^{3}$, Vesna Šimunić-Mežnarić4, \\ Nenad Martinec ${ }^{4}$, and José Manuel Lorenzo ${ }^{5}$ \\ ${ }^{1}$ Department of Hygiene, Technology and Food Safety, Faculty of Veterinary Medicine, University of Zagreb, \\ Zagreb, Croatia \\ ${ }^{2}$ Laboratory for Analytical Chemistry and Residues, Regional Department Split, Croatian Veterinary Institute, Split, \\ Croatia \\ ${ }^{3}$ PhD student, Lidl Hrvatska, Velika Gorica, Croatia \\ ${ }^{4}$ Bioinstitut d.o.o., Čakovec, Croatia \\ ${ }^{5}$ Centro Tecnológico de la Carne de Galicia, Parque Tecnológico de Galicia, San Cibrao das Viñas, Ourense, Spain
}

ZDOLEC, N., T. BOGDANOVIĆ, V. PAŽIN, V. ŠIMUNIĆ-MEŽNARIĆ, N. MARTINEC, J. M. LORENZO: Control of biogenic amines in dry sausages inoculated with dairy-originated bacteriocinogenic Enterococcus faecalis EF-101. Vet. arhiv 90, 77-85, 2020.

\section{ABSTRACT}

In this study, the dairy-originated bacteriocinogenic Enterococcus faecalis EF-101 strain was implemented in traditionally smoked Croatian home-made dry fermented sausages. During ripening, microbiological and physicochemical changes were observed, and the biogenic amines were monitored. The Enterococcus faecalis EF-101 count remained constant during the sausage ripening $\left(10^{5} \mathrm{CFU} / \mathrm{g}\right)$. There was no positive correlation of enterococci counts with cadaverine, histamine, tyramine, biogenic amines index, or total biogenic amines content in the sausages with added E. faecalis. The histamine and tyramine content correlated moderately with the lactic acid bacteria count in the control sausages. The total biogenic amines content was significantly higher $(\mathrm{P}<0.05)$ in the experimental sausages, however only on day 14 of ripening. The bacteriocinogenic strain of E. faecalis EF-101 reduced the histamine and cadaverine content, probably by reducing the aminogenic lactic acid bacteria population.

Key words: dry fermented sausage, Enterococcus faecalis, biogenic amines

\section{Introduction}

The production of traditionally fermented sausages and cured meats occurs worldwide and of course throughout Europe. In the Mediterranean region, sausages are traditionally mold- ripened without smoking, compared to North-European

technologies, which usually use smoke (LÜCKE, 2017). Several potential chemical hazards have been recognized in traditional non-starter fermented sausage production, such as: polycyclic aromatic hydrocarbons (smoking process), biogenic

\footnotetext{
*Corresponding author:

Nevijo Zdolec, Department of Hygiene, Technology and Food Safety, Faculty of Veterinary Medicine, University of Zagreb, Heinzelova 55, 10000 Zagreb, Croatia, E-mail: nzdolec@vef.hr
} 
amines (bacterial contamination) or mycotoxins (mold contamination) (ZDOLEC, 2017, 2018; LORENZO et al., 2007, 2010). One of the main chemical hazards, coupled with microbiological succession during sausage fermentation, would be the development and accumulation of biogenic amines. Sausage batter may be contaminated by persistent environmental microbiota, including an aminogenic population, due to poor hygiene conditions in households. Enterococci are the typical bacteria present for this reason, however, controversially, their presence and activity in sausage fermentation may even be desirable (SPARO et al., 2008). For instance, bacteriocins synthesized by enterococci have been characterized extensively and used in both food and animal production systems to reduce bacterial hazards (LAUKOVÁ, 2012). The antimicrobial activity of enterococci or enterocins in dry sausages has been shown to act mainly toward closely related Grampositive bacteria, including Listeria monocytogenes (SPARO et al., 2008).

Sources of enterocin-producing enterococci are varied, including animal/human feces, raw milk and milk products, meat, fish and fermented food (LAUKOVÁ, 2012; LAUKOVÁ et al., 2016; KUBAŠOVÁ et al., 2017). The knowledge regarding the performance of non-meat originated bacteriocin-producing enterococci in fermented sausages is still very limited (RUBIO et al., 2013; CENCI-GOGA et al., 2016). Thus, the objective of the present work was to evaluate the impact of the bacteriocinogenic Enterococcus faecalis EF101 strain, isolated from raw milk, on the safety and quality properties of traditionally smoked dry fermented sausages. The authors hypothesized that naturally fermented sausages inoculated with E. faecalis would pose a hazard, due to the development of biogenic amines.

\section{Materials and methods}

The Enterocin-producing culture of Enterococcus faecalis EF-101. Enterococcus faecalis EF-101 was isolated from raw cow milk and identified by MALDI-TOF MS (ZDOLEC et al., 2016; DOBRANIĆ et al., 2016). The inhibitory activity of the strain has been recently reported in foodborne strains of $L$. monocytogenes by enterocin production in vitro (CRK and ZDOLEC, 2018).

For the purpose of sausage inoculation, the strain of Enterococcus faecalis EF-101 was grown in MRS broth (Merck, Darmstadt, Germany) for $24 \mathrm{~h}$ at $37^{\circ} \mathrm{C}$, followed by enumeration of the cell count in $1 \mathrm{~mL}$ of culture. The cells were separated from the culture by centrifugation $(14,000 \mathrm{~g}$ for $10 \mathrm{~min}$ at $4{ }^{\circ} \mathrm{C}$ ) and washed twice in distilled water. The cells were diluted in $1 \mathrm{~mL}$ of sterile distilled water, and the cell number was determined using Compass Enterococcus agar (Biokar, Allonne, France) at $44{ }^{\circ} \mathrm{C}$ for $24 \mathrm{~h}$. For the batter inoculation, a serial dilution was selected to adjust the final number to $1 \times 10^{5}$ cells per gram of sausage mixture.

Sausage production and sampling. Two series of traditional dry fermented sausages were produced during the winter season in the study household. The raw materials were purchased from an export meat factory, and were thus expected to have a low level of microbial contamination. The pork neck meat and fat were chopped, and then mixed manually with $2 \%$ of $\mathrm{NaCl}$ and commercial spice mixture (Derma, Varaždin, Croatia). The batter was divided into two equal parts and the second was inoculated with a freshly prepared culture of $E$. faecalis $\mathrm{EF}-101\left(10^{5} \mathrm{CFU} / \mathrm{g}\right)$. The sausage mixtures were stuffed into natural swine casings, desalted in warm water ( $\varphi$ 38-42 mm, Derma, Varaždin). After stuffing, the sausages were hung in smoking cabins to drain and equilibrate to the outdoor temperature for one day. On the second day, the sausages were smoked by slowly combusting beech (Fagus) and hornbeam wood (Carpinus). The smoke was applied for several hours every second day and repeated five times. Smoke was generated in a firebox separated from the smoking area, and transferred to the hanging sausages by metal pipe ( $\varphi 100 \mathrm{~mm}$ ). After smoking, the sausages were ripened and dried in an attic for 40 days after stuffing. The sausages were sampled on the $0^{\text {th }}, 7^{\text {th }}, 14^{\text {th }}, 30^{\text {th }}$ and $40^{\text {th }}$ days of production.

Microbiological analyses. For the microbiological analyses, $25 \mathrm{~g}$ of sample was diluted in $225 \mathrm{~mL}$ of saline peptone water and homogenized for $2 \mathrm{~min}$ at 200 rpm (Stomacher Circular 400, Seward, United Kingdom). The initial dilutions were serially 
diluted and then, as appropriate, $1 \mathrm{~mL}$ or $0.1 \mathrm{~mL}$ of the relevant dilutions were used for enumeration of the microbiota, as follows: total viable count was checked on Plate Count agar (BioMérieux, Marcy l'Etoile, France) incubated at $30{ }^{\circ} \mathrm{C}$ for $72 \mathrm{~h}$, lactic acid bacteria onto MRS agar (Merck, Darmstadt, Germany) at $30^{\circ} \mathrm{C}$ for $48 \mathrm{~h}$, enterococci onto Compass Enterococcus agar (Biokar, Allonne, France) at $44{ }^{\circ} \mathrm{C}$ for $24 \mathrm{~h}$, yeast and molds onto Yeast Glucose Chloramphenicol agar (Merck) at $25{ }^{\circ} \mathrm{C}$ for 5 days, coagulase positive staphylococci onto Baird-Parker agar (Merck) at $37{ }^{\circ} \mathrm{C}$ for $48 \mathrm{~h}$, Listeria monocytogenes onto ALOA agar (Oxoid, Basingstoke, United Kingdom) at $37^{\circ} \mathrm{C}$ for $48 \mathrm{~h}$ and Yersinia enterocolitica onto CIN agar (BioMérieux) at $30{ }^{\circ} \mathrm{C}$ for $24 \mathrm{~h}$. Each sample was analyzed twice and, on the basis of the results obtained, the mean values were calculated.

Physico-chemical analyses. The quantity of protein, fat, and water was determined using a NIR spectrophotometer (Bruker Tango FT-NIR). The NIR spectrum encompasses a wide range of overlapping spectral absorption bands which correspond to more complex molecular vibrations and frequencies (overtones and combinations of basic vibrations). The NIR region covers electromagnetic radiation over the wavelengths from 750-2500 $\mathrm{nm}$. In that range molecules that contain $\mathrm{C}-\mathrm{H}, \mathrm{N}-\mathrm{H}$ and $\mathrm{O}-\mathrm{H}$ bonds (fats, proteins, carbohydrates, organic acids, alcohol and water) are absorbed. Homogenized samples were placed into glass dishes and subsequently measured by the NIR spectrophotometer. Each sample was measured twice and, on the basis of the results obtained, the mean values were calculated. The $\mathrm{NaCl}$ quantity was obtained using the Mohr method (KAMENÍK et al., 2017), the $\mathrm{pH}$ value was determined using a digital $\mathrm{pH}$ meter in the extract $(\mathrm{pH} 510$ Eutech Instruments, Landsmeer, Netherlands), and the water activity $\left(\mathrm{a}_{\mathrm{w}}\right)$ was measured by means of a HigroPalm AW1 device (Rotronic, Bassersdorf, Switzerland). Each sample was measured twice, and on the basis of the results obtained, the mean values were calculated.

Determination of biogenic amines (BA). The eight biogenic amines studied (Cadaverine CAD, Histamine - HIS, phenyletilamine PHE,
Putrescine - PUT, Spermidine SPD, Spermine SPM, Tryptamine - TRP and Tyramine - TIR) were detected and quantified by high performance liquid chromatography, using a diode array detector (G1315B DAD, Agilent Technologies) at 254 $\mathrm{nm}$, with $550 \mathrm{~nm}$ as a reference after precolumn derivatization with dansyl chloride, as described by EEROLA et al. (1993). The extraction of 2.5 $\mathrm{g}$ of homogenized sample without casing was performed in $25 \mathrm{~mL} 0.4 \mathrm{~mol} / \mathrm{L}$ perchloric acid. A total of $125 \mu \mathrm{L}$ of an internal standard solution (1.7 heptanediamine, $1000 \mathrm{mg} / \mathrm{L}$ ) was added to the homogenized sample prior to the extraction with $0.4 \mathrm{M}$ perchloric acid. One milliliter of filtered sausage extract or mixed standard solution of biogenic amines was alkalized by adding 200 $\mu \mathrm{L}$ of $\mathrm{NaOH}$ solution $(2 \mathrm{~mol} / \mathrm{L})$ and $300 \mu \mathrm{L}$ of a saturated sodium bicarbonate $\left(\mathrm{NaHCO}_{3}\right)$ solution. Derivatization was obtained by thoroughly mixing with $2 \mathrm{~mL}$ of a dansyl chloride solution in acetone $(10 \mathrm{mg} / \mathrm{mL})$, followed by incubation (45 $\mathrm{min}$ at $\left.40{ }^{\circ} \mathrm{C}\right)$. Residual dansyl chloride was removed by adding $150 \mu \mathrm{L}$ of ammonia solution $(1 \mathrm{~mol} / \mathrm{L}$ $\mathrm{NH}_{4} \mathrm{OH}$ ), and the solution was kept in the dark for $45 \mathrm{~min}$. Acetonitrile was added to a total volume of $5 \mathrm{~mL}$ followed by filtration using a $0.45 \mu \mathrm{m}$ syringe filter (Sartorius, Goettingen, Germany).

The HPLC analysis of the BAs was performed using an High Performance Liquid Chromatograph (Agilent 1200 Series HPLC, Santa Clara, CA) equipped with a binary gradient pump (G1312A), and an auto-sampler with a thermostated sample compartment (G1329A), a thermostated column compartment (G1316A) and a DAD detector (G1315D). The separation of the compounds was undertaken in an LiChrospher C18 analytical column (ID $250 \mathrm{~mm} \times 4.0 \mathrm{~mm}$, particle size $5 \mu \mathrm{m}$ ) using a C18 Security Guard Cartridge(ID $4 \mathrm{~mm} \times 3.0 \mathrm{~mm}$ ) supplied by Phenomenex (Agilent, Santa Clara, CA), which was maintained at $40{ }^{\circ} \mathrm{C}$ and processed the injection volume of $20 \mu \mathrm{L}$. The mobile phase was a mixture of $\mathrm{ACN}$ and $0.1 \mathrm{~mol} / \mathrm{L}$ ammonium acetate in a gradient mode, flowing at the rate of $1 \mathrm{ml} / \mathrm{min}$ (EEROLA et al., 1993). The initial 50\% ACN representation was increased to $90 \%$ in 19 $\mathrm{min}$. The initial conditions were reached in a minute, and maintained for $9 \mathrm{~min}$ before the next run. The 
total run time was $29 \mathrm{~min}$. The compounds were quantified using internal calibrations curves plotted for each BA and covering, for eight concentration levels ranging from $0.125-10 \mathrm{mg} / \mathrm{L}$. Limits of quantification $(\mathrm{mg} / \mathrm{kg}$ wet weight) ranged from 0.30 $\mathrm{mg} / \mathrm{kg}$ (cadaverine) to $0.40 \mathrm{mg} / \mathrm{kg}$ (histamine and putrescine). Each sample of fermented sausages was analyzed in duplicate, and the BAs content values stated herein thereby represent the mean of these two parallel analyses.

Statistical analysis. Statistical analyses were performed using STATISTICA Version 12 (StatSoft. Inc., 2012). Differences in biogenic amines content between the two groups were evaluated by t-test $(\mathrm{P}<0.05)$. The correlation coefficient $\mathrm{R}$ was calculated at the level of significance of $\mathrm{P}<0.05$ to evaluate the relationship between the determined microbial counts and biogenic amines.

\section{Results and discussion}

\section{Microbiological and physico-chemical} parameters. The total viable count in the control sausages was $1 \log$ lower compared to sausages with the E. faecalis strain until day 30 (Table 1), while in the final sausages it was equal in both groups. The population of enterococci in the control sausages was low - below the detection limit by this method (2 log CFU/g), suggesting good hygiene standards in meat production. The enterococcal count in the inoculated sausages remained constant during the manufacturing process $(5 \log \mathrm{CFU} / \mathrm{g})$. The lactic acid bacteria count was 1-2 log higher during the ripening in the sausages inoculated with E. faecalis EF-101. A growth of LAB was recorded in the control sausages, while in the experimental group it was constant at the level of $5 \log \mathrm{CFU} / \mathrm{g}$. The L. monocytogenes, $Y$. enterocolitica, S. aureus and Pseudomonas spp. counts were below the limit of detection $(<2 \log \mathrm{CFU} / \mathrm{g})$.

Enterococci are part of the normal microflora of fermented sausages, but vary considerably with regards to the number in the population in different types of products (GARCÍA FONTÁN et al. 2007; MILIČEVIĆ et al., 2014). In our control batter, enterococci were present in very low numbers. The lactic acid bacteria and aerobic mesophilic bacteria showed a trend towards growth, mostly in the initial fermentation phase as reported by others (KOZAČINSKI et al., 2006; ZDOLEC et al., 2008; LORENZO et al., 2012). Enterococci can survive and multiply during fermentation in meat products, especially in products made without the use of competitive starter cultures (HUGAS et al., 2003). After the inoculation of bacteriocinogenic strain E. faecalis EF-101 from milk into the sausage batter $\left(10^{5} \mathrm{CFU} / \mathrm{g}\right)$, the number of enterococci did not change significantly during ripening. Since the population was stable, we can assume that the strain adapted to the conditions of meat fermentation, although further research and experimental production are required. The sensorial properties of sausages produced with the strain E. faecalis EF101 were reported as acceptable by ČOP (2016). RUBIO et al. (2013) investigated the applicability of three bacteriocinogenic strains of enterococci in low acid fermented sausages, with the aim of reducing the population of $L$. monocytogenes and $S$. aureus. All three strains were shown to successfully transform the natural microflora of enterococci and two strains completely inhibited the growth of $L$. monocytogenes. SPARO et al. (2008) used a dairy culture of Enterococcus faecalis CECT7121 in the production of fermented sausages, and found no statistically significant differences between the control and experimental sausages with respect to the production of lactic acid and $\mathrm{pH}$ oscillation. Sausages with inoculated E. faecalis CECT7121 had a lower count of enterobacteriae, $S$. aureus and other Gram-positive cocci at the end of fermentation (SPARO et al., 2008).

As shown in Table 1, the content of proteins, fat and salt increased with the progression of ripening and drying $(\mathrm{R}>0.91 ; \mathrm{P}<0.05)$, along with a lowering of the moisture and water activity $(\mathrm{R}=-$ $0.99 ; \mathrm{P}<0.05)$. The $\mathrm{pH}$ values and their trend were as expected in this kind of product. However, differences between groups were observed in $\mathrm{pH}$ values; $\mathrm{pH}$ was $0.2-0.3$ lower in sausages inoculated with the bacteriocinogenic strain. This finding is in agreement with data reported by LORENZO et al. (2014); lower $\mathrm{pH}$ values were noted in sausages produced with the starter strain compared to the control group. 


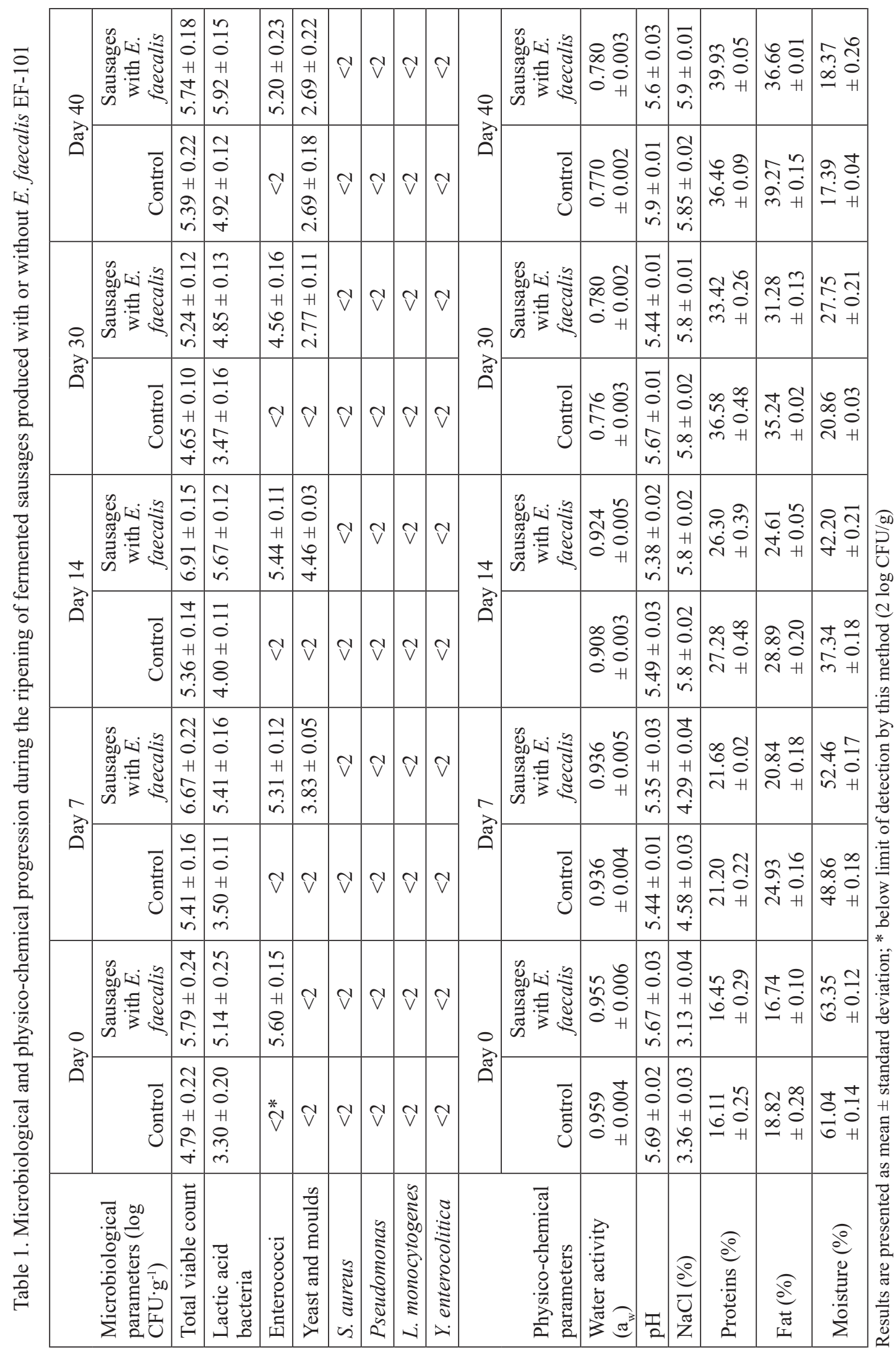




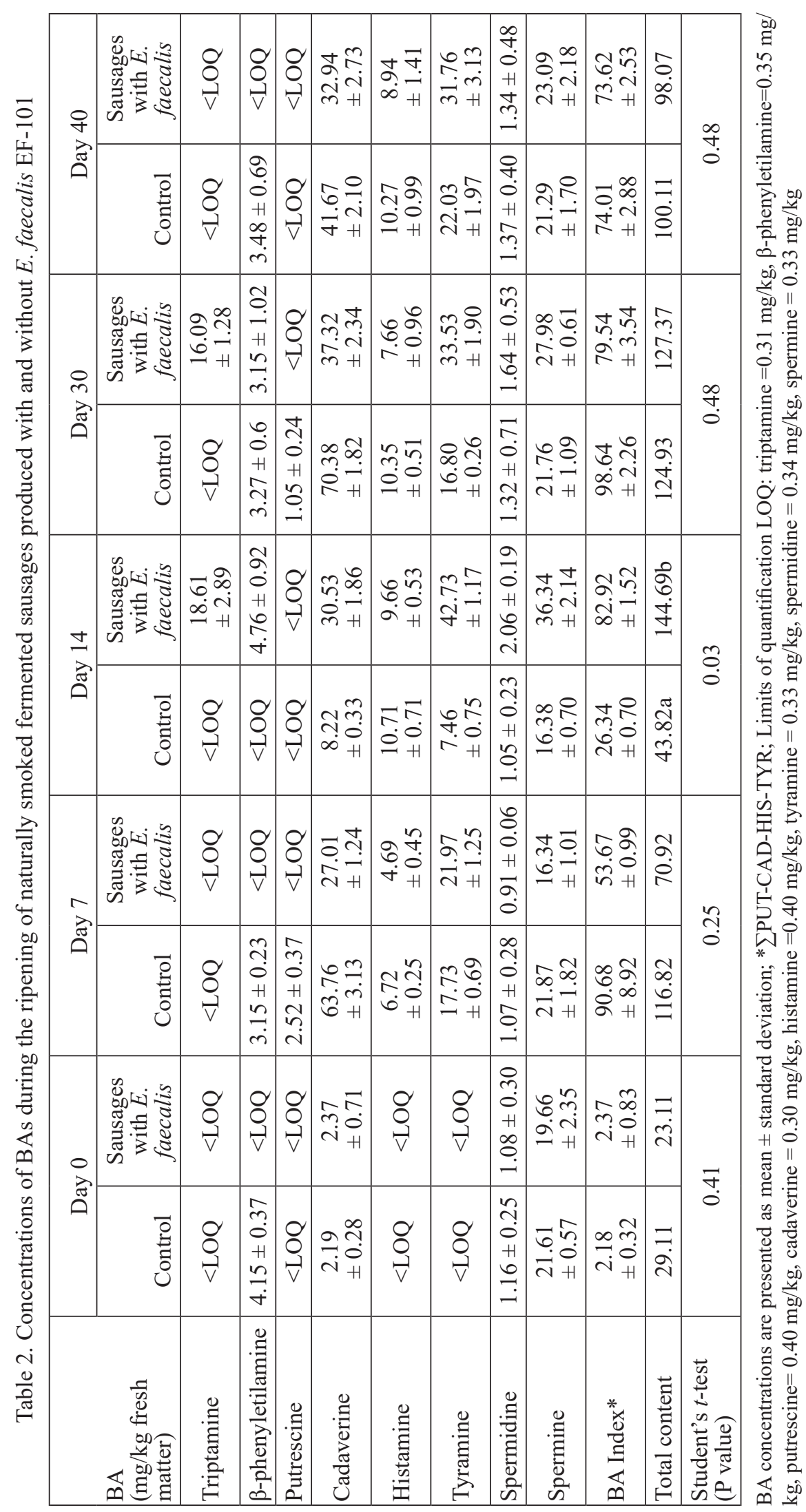


Biogenic amines. In general, the highest amount of amines tested was recorded for cadaverine, tyramine and spermine during product ripening (Table 2). The histamine content was lower in sausages with the bacteriocinogenic strain during the whole ripening process. Moreover, the quantity of cadaverine was also lower in sausages with the E. faecalis strain, except on day 14 . On the other hand, tyramine content was lower in the control sausages on all sampling days. The BA index (the sum of putrescine, histamine, cadaverine, and tyramine) was below $5 \mathrm{mg} / \mathrm{kg}$ in both sausage mixtures, indicating the good hygiene standards of the raw material used. The highest differences in the BA index were observed on day 7 (highest in the control) and day 14 (highest in the experimental sausages). The total content of BA was statistically significantly higher $(\mathrm{P}<0.05)$ in the experimental sausages on day 14 , while there was no difference between the sausages during the other production phases $(\mathrm{P}>0.05)$. There was no positive correlation of enterococci counts and cadaverine, histamine, tyramine, BA index, or total BA content in the sausages with the added E. faecalis strain. In the control sausages, the histamine and tyramine content correlated moderately with the LAB count ( $R=0.56$ and 0.54 , respectively).

The main biogenic amines developed in fermented meat products are tyramine, cadaverine, putrescine, and histamine (RUIZ-CAPILLAS and JIMÉNEZ-COLMENERO, 2004; DOMÍNGUEZ et al., 2016; PLEADIN and BOGDANOVIĆ, 2017). ANSORENA et al. (2002) reported that the tyramine and putrescine content ranged from 76 to $187 \mathrm{mg} / \mathrm{kg}$ and from 33 to $125 \mathrm{mg} / \mathrm{kg}$, respectively. However, in our study, the putrescine content was below the limit of quantification $(0.40 \mathrm{mg} /$ $\mathrm{kg}$ ). Tyramine is another important amine from a toxicology point of view, and its toxicological level ranges from $150-800 \mathrm{mg} / \mathrm{kg}$. Tyramine production has been reported in the majority of enterococci from fermented sausages (BOVER-CID and HOLZAPFEL, 1999), which may be related to our finding of higher tyramine content in sausages with the E. faecalis strain. Histamine is the most important biogenic amine from a toxicology point of view (SHALABY, 1996). In our study, a slight accumulation of histamine was observed in both batches (10.27 and $8.94 \mathrm{mg} / \mathrm{kg}$ ), which is much lower than its upper limits in food (100-400 $\mathrm{mg} / \mathrm{kg}$ ) (ZHANG et al., 2013). In addition, our values were lower than the mean values reported by EFSA (2011) for European sausages (about $25 \mathrm{mg} / \mathrm{kg}$ ). Besides the microbiological factors (VESKOVIC MORACANIN et al., 2015), the amine content depends on conditions such as $\mathrm{pH}$ values, temperature, salt content, and sausage diameter (LATORRE-MORATALLA et al., 2008; LORENZO et al., 2010). The strategies for reduction of biogenic amines in fermented sausages should be primarily based on quality control of the raw material, and the use of competitive starter cultures (LORENZO et al., 2017; BEHERA et al., 2018).

In conclusion, simulation of high-level contamination/inoculation of sausage batter by Enterococcus faecalis EF-101 resulted in a higher content of biogenic amines on day $14(\mathrm{P}<0.05)$, but not during the other production phases. In addition, our study showed that the presence of the bacteriocinogenic E. faecalis EF-101 strain in sausage fermentation affected the histamine and cadaverine content, probably by reducing the level of aminogenic LAB.

\section{Acknowledgments}

Authors acknowledge the financial support of the Ministry of Science and Education/University of Zagreb. Jose M. Lorenzo is a member of the MARCARNE network, funded by CYTED (ref. 116RT0503).

\section{References}

ANSORENA, D., M. C. MONTEL, M. ROKKA, R. TALON, S. EEROLA, A, RIZZO, M. RAEMAEKERS, D. DEMEYER (2002): Analysis of biogenic amines in northern and southern European sausages and role of flora in amine production. Meat Sci. 61, 141-147.

DOI: 10.1016/S0309-1740(01)00174-7

BEHERA, S. S., R. C. RAY, N. ZDOLEC (2018): Lactobacillus plantarum with functional properties: an approach to increase safety and shelf-life of fermented foods. BioMed. Res. Int. 9361614, 18 pages.

DOI: $10.1155 / 2018 / 9361614$ 
BOVER-CID, S., W. H. HOLZAPFEL (1999): Improved screening procedure for biogenic amine production by lactic acid bacteria. Int. J. Food Microbiol. 53, 33-41.

DOI: 10.1016/S0168-1605(99)00152-X

CENCI-GOGA, B. T., M. KARAMA, P. SECHI, M. F. IULIETTO, S. NOVELLI, R. SELVAGINNI, S. BARBERA (2016): Effect of a novel starter culture and specific ripening conditions on microbiological characteristics of nitrate-free dry-cured pork sausages. Ital. J. Anim. Sci. 15, 358-374.

DOI: $10.1080 / 1828051 X .2016 .1204633$

CRK, D., N. ZDOLEC (2018): Antimicrobial potential of enterococci isolated from raw milk. Hrvatski veterinarski vjesnik, 26, 30-34. (in Croatian).

ČOP, M. (2016): Quality of home-made fermented sausages produced with culture of Enterococcus faecalis 101. Graduate Thesis, Faculty of Veterinary Medicine, University of Zagreb, Zagreb, Croatia.

DOBRANIĆ, V., S. KAZAZIĆ, I. FILIPOVIĆ, N. MIKULEC, N. ZDOLEC (2016): Composition of raw cow's milk microbiota and identification of enterococci by MALDITOF MS - short communication. Vet. arhiv 86, 581-590. https://hrcak.srce.hr/166060

DOMÍNGUEZ, R., P. E. S. MUNEKATA, R. AGREGÁN, J. M. LORENZO (2016): Effect of commercial starter cultures on free amino acid, biogenic amine and free fatty acid contents in dry-cured foal sausage. LWT-Food Sci. Technol. 71, 47-53.

DOI: $10.1016 /$ j.lwt.2016.03.016

EEROLA, S., R. HINKKANEN, E. LINDFORS, T. HIRVI (1993): Liquid chromatographic determination of biogenic amines in dry sausages. J. AOAC Int. 76, 575-578. https://www.ncbi.nlm.nih.gov/pubmed/8318851

EFSA (2011): Scientific opinion on risk based control of biogenic amine formation in fermented foods. EFSA Journal 9, 2393e2486.

DOI: $10.2903 /$ j.efsa.2011.2393

GARCÍA FONTÁN, M. C., J. M. LORENZO, S. MARTÍNEZ, I. FRANCO, J. CARBALLO (2007): Microbiological characteristics of Botillo, a Spanish traditional pork sausage. LWT-Food Sci. Technol. 40, 1610-1622.

DOI: $10.1016 /$ j.lwt.2006.10.007

HUGAS, M., M. GARRIGA, M. T. AYMERICH (2003): Functionality of enterococci in meat products. Int. J. Food Microbiol. 88, 223-233.

DOI: $10.1016 / \mathrm{S} 0168-1605(03) 00184-3$

KAMENÍK, J., A. SALÁKOVÁ, V. VYSKOČILOVÁ, A. PECHOVÁ, D. HARUŠTIAKOVÁ (2017): Salt, sodium chloride or sodium? Content and relationship with chemical, instrumental and sensory attributes in cooked meat products. Meat Sci. 131, 196-202.

DOI: 10.1016/j.meatsci.2017.05.010
KOZAČINSKI, L., N. ZDOLEC, M HADŽIOSMANOVIĆ, Ž. CVRTILA, I. FILIPOVIĆ, T. MAJIĆ (2006): Microbial flora of the Croatian traditionally fermented sausage. Arch. Lebensmittelhyg. 57, 141-147.

KUBAŠOVÁ, I., V. STROMPFOVÁ, A. LAUKOVÁ (2017): Safety assessment of commensal enterococci from dogs. Folia Microbiol. 62, 491-498.

DOI: $10.1007 / \mathrm{s} 12223-017-0521-\mathrm{z}$

LATORRE-MORATALLA, M. L., T. VECIANA-NOGUÉS, S. BOVER-CID, M. GARRIGA, T. AYMERICH, E. ZANARDI, A. IANIERI, M. J. FRAQUEZA, L. PATARATA, E. H. DROSINOS, A. LAUKOVÁ, R. TALON, M. C. VIDAL-CAROU (2008): Biogenic amines in traditional fermented sausages produced in selected European countries. Food Chem. 107, 912-921.

DOI: 10.1016/j.foodchem.2007.08.046

LAUKOVÁ, A. (2012): Potential applications of probiotic, bacteriocin-producing enterococci and their bacteriocins. In: Lactic Acid Bacteria: Microbiological and Functional Aspects. $4^{\text {th }}$ ed. (Lahtinen, S., A. C. Ouwehand, S. Salminen, A. von Wright, Eds.). CRC Press, Taylor \& Francis Group, Boca Raton, pp. 39-61.

LAUKOVÁ, A., A. KANDRIČÁKOVÁ, J. ŠČERBOVÁ, V. STROMPFOVA (2016): Enterococci isolated from farm ostriches and their relation to enterocins. Folia Microbiol. 61, 275-281.

DOI: $10.1007 / \mathrm{s} 12223-015-0435-6$

LORENZO, J. M., A. CACHALDORA, S. FONSECA, M. GÓMEZ, I. FRANCO, J. CARBALLO (2010): Production of biogenic amines "in vitro" in relation to the growth phase by Enterobacteriaceae species isolated from traditional sausages. Meat Sci. 86, 684-691.

DOI: 10.1016/j.meatsci.2010.06.005

LORENZO, J. M., D. FRANCO, J. CARBALLO (2017): Biogenic amines in fermented meat products. In: Fermented Meat Products: Health Aspects. (Zdolec, N., Ed.). Boca Raton, USA: CRC Press Taylor \& Francis, 450-473.

LORENZO, J. M., M. GÓMEZ, S. FONSECA (2014): Effect of commercial starter cultures on physicochemical characteristics, microbial counts and free fatty acid composition of dry-cured foal sausage. Food Control 46, 382-389.

DOI: 10.1016/j.foodcont.2014.05.025

LORENZO, J. M., S. MARTÍNEZ, I. FRANCO, J. CARBALLO (2007): Biogenic amine content in relation to physicochemical parameters and microbial counts in two kinds of Spanish traditional sausages. Archiv Lebensmittelhyg. 59, 70-75.

LORENZO, J. M., S. TEMPERÁN, R. BERMÚDEZ, N. COBAS, L. PURRIÑOS (2012): Changes in physicochemical, microbiological, textural and sensory attributes during ripening of dry-cured foal salchichón. Meat Sci. 90, 194-198.

DOI: 10.1016/j.meatsci.2011.06.025 
LÜCKE, K. F. (2017): Fermented meat products-an overview. In: Fermented meat products: health aspects. (Zdolec, N., Ed.). Boca Raton, USA: CRC Press Taylor \& Francis, pp. $1-14$.

MILIČEVIĆ, B., B. DANILOVIĆ, N. ZDOLEC, L. KOZAČINSKI, V. DOBRANIĆ, D. SAVIĆ (2014): Microbiota of the fermented sausages: influence to product quality and safety. Bulg. J. Agric. Sci. 20, 1061-1078. www.agrojournal.org/20/05-07.html

PLEADIN, J., T. BOGDANOVIĆ (2017): Chemical hazards in fermented meat. In: Fermented Meat Products: Health Aspects. (N. Zdolec, Ed.). Boca Raton, USA: CRC Press Taylor \& Francis, pp. 417-449.

RUBIO, R., S. BOVER-CID, B. MARTIN, M. GARRIGA, T. AYMERICH (2013): Assessment of safe enterococci as bioprotective cultures in low-acid fermented sausages combined with high hydrostatic pressure. Food Microbiol. 33, 158-165.

DOI: $10.1016 /$ j.fm.2012.09.012

RUIZ-CAPILLAS, C., F. JIMÉNEZ-COLMENERO (2004): Biogenic amines in meat and meat products. Crit. Rev. Food Sci. Nutr. 44, 489-499.

DOI: 10.1080/10408690490489341

SHALABY, A. R. (1996): Significance of biogenic amines to food safety and human health. Food Res. Int. 29, 675-690. DOI: 10.1016/S0963-9969(96)00066-X

SPARO, M, G. G. NUÑEEZ, G. G., M. GASTRO, M. L. CALCAGNO, M. A. GARCIA ALLENDE, M. CECI, R. NAJLE, M. MANGHI (2008): Characterictics of an environmental strain, Enterococcus faecalis CECT7121, and its effects as -additive on craft dry-fermented sausages. Food Microbiol. 25, 607-615.

DOI: $10.1016 /$ j.fm.2008.01.008

STATSOFT (2012): STATISTICA ver. 12.

http://www.statsoft.com/Products/STATISTICA-Features
VESKOVIC MORACANIN, S., S. STEFANOVIC, T RADICEVIC, B. BOROVIC, D, DJUKIC (2015): Production of biogenic amines by lactic acid bacteria isolated from Uzicka sausages. Proc. Food Sci. 5, 308-311. DOI: 10.1016/j.profoo.2015.09.068

ZDOLEC, N. (2018): Technological interventions in fermented meat production: the commercial perspective. In: Innovations in Technologies for Fermented Food and Beverage Industries, Food Microbiology and Food Safety. (Panda, S. K., P. H. Shetty, Eds.), Springer International Publishing AG, Cham, pp. 175-188.

DOI: $10.1007 / 978-3-319-74820-7 \_10$

ZDOLEC, N. (2017): Fermented meat products: health aspects. Boca Raton, USA: CRC Press Taylor \& Francis.

ZDOLEC, N., V. DOBRANIĆ, I. BUTKOVIĆ, A. KOTURIĆ, I. FILIPOVIĆ, V. MEDVID (2016): Antimicrobial susceptibility of milk bacteria from healthy and drugtreated cow udder. Vet. arhiv 86, 163-172.

https://hrcak.srce.hr/156704

ZDOLEC, N., M. HADŽIOSMANOVIĆ, L. KOZAČINSKI, Ž. CVRTILA, I. FILIPOVIĆ, M. ŠKRIVANKO, K. LESKOVAR (2008): Microbial and physicochemical succession in fermented sausages produced with bacteriocinogenic culture of Lactobacillus sakei and semipurified bacteriocin mesenterocin Y. Meat Sci. 80, 480-487.

DOI: 10.1016/j.meatsci.2008.01.012

ZHANG, Q., S.LIN, X.NIE(2013): Reduction of biogenic amine accumulation in silver carp sausage by an amine-negative Lactobacillus plantarum. Food Control 32, 496-500. DOI: $10.1016 /$ j.foodcont.2013.01.029

Received: 17 August 2018

Accepted: 21 December 2018

ZDOLEC, N., T. BOGdANOVIĆ, V. PAŽIN, V. ŠIMUNIĆ-MEŽNARIĆ, N. MARTINEC, J. M. LORENZO: Biogeni amini u trajnim kobasicama inokuliranima bakteriocinogenom kulturom Enterococcus faecalis EF-101 iz mlijeka. Vet. arhiv 90, 77-85, 2020.

\section{SAŽETAK}

U ovom je istraživanju primijenjena bakteriocinogena kultura Enterococcus faecalis EF-101 iz mlijeka u proizvodnji trajnih kobasica u domaćinstvu. Tijekom zrenja praćene su mikrobiološke i fizikalno-kemijske promjene u nadjevu te sastav i količina biogenih amina. Broj E. faecalis ostao je stalan tijekom zrenja kobasica $\left(10^{5} \mathrm{CFU} / \mathrm{g}\right)$. Nije zabilježena povezanost broja enterokoka i količine kadaverina, histamina, tiramina, indeksa biogenih amina i ukupnih amina. U kontrolnim je kobasicama količina histamina i tiramina umjereno korelirala s brojem bakterija mliječne kiseline. Ukupna količina biogenih amina u pokusnim je kobasicama bila znakovito veća $(\mathrm{P}<0,05)$ tek 14 . dan zrenja. Istraživanje je pokazalo da bakteriocinogena kultura E. faecalis EF-101 reducira količinu histamina i kadaverina, vjerojatno sistiranjem aminogene mikroflore.

Ključne riječi: trajne kobasice; Enterococcus faecalis; biogeni amini 
